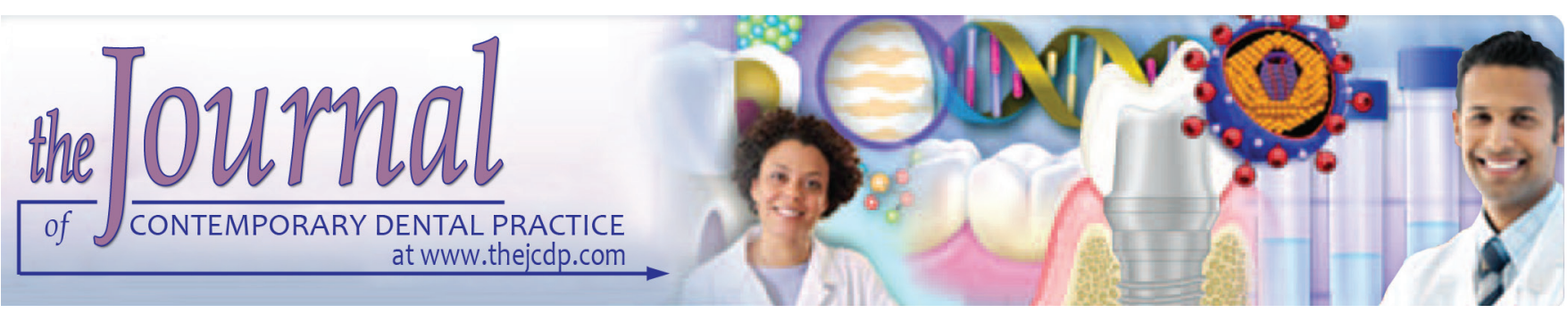

\title{
Antimicrobial and Antiproliferative Activity of Bauhinia forficata Link and Cnidoscolus quercifolius Extracts commonly Used in Folk Medicine
}

${ }^{1}$ Erika P Alves, ${ }^{2}$ Rennaly de F Lima, ${ }^{3}$ Carolina M de Almeida, ${ }^{4}$ Irlan A Freires, ${ }^{5}$ Pedro L Rosalen, ${ }^{6}$ Ana LTG Ruiz

${ }^{7}$ Ana F Granville-Garcia, ${ }^{8}$ Gustavo P Godoy, ${ }^{9}$ Jozinete V Pereira, ${ }^{10}$ Edja MM de Brito Costa

\begin{abstract}
Background: Bauhinia forficata and Cnidoscolus quercifolius plants are commonly used in folk medicine. However, few studies have investigated their therapeutic potential.
\end{abstract}

Aim: Herein, we evaluated the antimicrobial activity of $B$. forficata and $C$. quercifolius extracts against microorganisms of clinical relevance and their antiproliferative potential against tumor cells.

Materials and methods: The following tests were performed: Minimum inhibitory concentration (MIC) and minimum bactericidal concentration (MBC)/minimum fungicidal concentration (MFC), inhibition of biofilm adhesion, and effects on cell morphology. Antiproliferative tests were carried out with human keratinocytes and six tumor lines.

Results: Bauhinia forficata showed antimicrobial activity only against $C$. albicans with MIC of $15.62 \mu \mathrm{g} / \mathrm{mL}$ and MFC higher than $2000 \mu \mathrm{g} / \mathrm{mL}$. It also inhibited biofilm adhesion and caused alterations in cell morphology. Cnidoscolus quercifolius showed no significant activity (MIC $>2.0 \mathrm{mg} / \mathrm{mL}$ ) against the strains. Bauhinia forficata and C. quercifolius extracts showed cytostatic activity against the tumor cells.

Conclusion: Bauhinia forficata has promising anti-Candida activity and should be further investigated for its therapeutic potential.

Clinical significance: The use of medicinal plants in the treatment of infectious processes has an important function

\footnotetext{
1-3,7-10Department of Dentistry, Paraiba State University Campina Grande, Paraiba, Brazil

${ }^{4,5}$ Department of Physiological Science, University of Campinas Piracicaba, São Paulo, Brazil

${ }^{6}$ Department of Chemistry, Center for Chemical, Biological and Agricultural Research, University of Campinas, Campinas, São Paulo, Brazil

Corresponding Author: Edja MM de Brito Costa, Department of Dentistry, Paraiba State University, Campina Grande, Paraiba Brazil, Phone: +5583999969623, e-mail: edjacosta@gmail.com
}

nowadays, due to the limitations of the use of synthetic antibiotics available, related specifically to the microbial resistance emergence.

Keywords: Antimicrobial activity, Antiproliferative effect, Biofilm adhesion, Candida biofilm, Laboratory research, Medicinal plants.

How to cite this article: Alves EP, de F Lima R, de Almeida CM, Freires IA, Rosalen PL, Ruiz ALTG, Granville-Garcia AF, Godoy GP, Pereira JV, de Brito Costa EMM. Antimicrobial and Antiproliferative Activity of Bauhinia forficata Link and Cnidoscolus quercifolius Extracts commonly Used in Folk Medicine. J Contemp Dent Pract 2017;18(8):635-640.

Source of Support: Nil

Conflict of Interest: None

\section{INTRODUCTION}

At present, drugs derived from natural products are capable of treating $87 \%$ of human illnesses, either bacterial, parasitic, immunosuppressant, carcinogenic, or others. ${ }^{1}$ In addition, scientific studies have continuously advanced the knowledge of the therapeutic properties of medicinal plants used in folk medicine.

The species Bauhinia forficata Link, genus Bauhinia L. has been considered as a tonic, expectorant, hypocholesterolemic, hypoglycemic, antimicrobial, antihypertensive, and anti-inflammatory agent. ${ }^{2}$ The major presence of flavonoids in its chemical composition has been associated with various pharmacological activities. ${ }^{3}$ The traditional use of $B$. forficata as a hypoglycemic is related to its antioxidant activity and the presence of an insulin-like protein in its flavonoid derivatives. ${ }^{2-5}$

Another plant widely used in folk medicine is Cnidoscolus quercifolius Pohl, genus Cnidoscolus, whose bark and stem are used as anti-inflammatory, diuretic, disinfectant, wound healing, antitumor for the genitourinary 
tract, antiseptic and dressing for dermatological and ophthalmic infections, fractures, dysentery, appendicitis, rheumatism, influenza, cough, and also for tooth, ear, and back pain. ${ }^{6,7}$ The latex produced in this plant is used in the cauterization and coagulation of wounds and the bark poultice for wound healing. ${ }^{8}$ Other parts of the plant are also used for therapeutic purposes, such as the root and shoots. ${ }^{6,9}$ Despite the fact that these plants are widely used in traditional medicine, there is still a need for scientific evidence on their biological and therapeutic properties, especially with regard to prevention and/or treatment of oral diseases.

Considered the most common infectious diseases of the oral cavity, tooth decay and candidiasis are associated with the formation of a biofilm structure, composed mainly of streptococci and Candida spp. cells respectively, embedded in a polymeric matrix. ${ }^{10}$ One of the mechanisms to control this biofilm formation consists in the use of antimicrobials. However, microbial resistance, especially in Candida spp., has increased in recent decades, constituting a serious problem for public health. ${ }^{10,11}$ Conventional antifungals have limitations related to toxicity, which encourages the discovery of new antifungal compounds that act at different cellular targets with fewer side effects. ${ }^{12-14}$ Regarding the control of oral biofilm, chlorhexidine stands out for being a large-spectrum antiseptic acting on Gram-positive and Gram-negative bacteria and fungi. Nevertheless, it has adverse effects, such as taste alteration, teeth staining, and imbalance of the oral microbiota. With this perspective, studies on medicinal plants have been targeting the discovery of new chemical molecules able to overcome the shortcomings of synthetic agents currently used in medicine and dentistry. ${ }^{15-18}$

In this bioprospection study, we evaluated the antimicrobial activity of hydroalcoholic extracts of $B$. forficata and $C$. quercifolius against microorganisms of clinical relevance, particularly in oral candidiasis, and their antiproliferative potential against six tumor cell lines and keratinocytes.

\section{MATERIALS AND METHODS}

\section{Plant Material}

Bauhinia forficata and C. quercifolius leaves were collected in the semiarid region in the Paraiba state, Serra de Bodocongó, municipality of Queimadas ( $7^{\circ} 22^{\prime} 25^{\prime \prime} \mathrm{S}, 35^{\circ}$ $59^{\prime} 32^{\prime \prime} \mathrm{W}$ ), in the mesoregion of Borborema and microregion of Cariri Oriental, PB, Brazil, in September. Voucher specimens were deposited in the collection of the Manuel de Arruda Câmara Herbarium (ACAM), State University of Paraíba (Universidade Estadual da Paraíba - UEPB),
Campus I, Campina Grande, Paraíba, under no. 130/ ACAM and no. 017/ ACAM respectively.

\section{Preparation of Extracts}

Bauhinia forficata bark and C. quercifolius leaves were dehydrated in an air-circulating oven at $40^{\circ} \mathrm{C}$, subsequently ground and immersed in $80 \%$ ethyl alcohol $(100 \mathrm{~g} / 250 \mathrm{~mL})$ for 48 hours at room temperature. The resulting mixture was filtered, and the filtration residue was immersed twice in the solvent. The final phases were concentrated on a vacuum rotary evaporator at $39^{\circ} \mathrm{C}$, and subsequently lyophilized.

\section{Microorganisms}

The reference strains of Candida albicans ATCC 18804, Streptococcus mutans ATCC 25175, Streptococcus sanguis ATCC 10557, and Enterococcus faecalis ATCC 29212 were used in this study. The strains were maintained as frozen stocks at $-80^{\circ} \mathrm{C}$ until use. For the assays, the strains were subcultured in specific culture media and incubated under specific atmosphere conditions at 35 to $37^{\circ} \mathrm{C}$ for 24 hours.

\section{Determination of the Minimum Inhibitory Concentration and Fungicidal/Bactericidal Concentrations}

The antimicrobial activity of the extracts was identified by determining their MIC and minimum bactericidal concentration (MBC) or MFC, as previously described by the Clinical and Laboratory Standards Institute. ${ }^{19,20}$ The tests were performed using 96-well microtiter plates, Brain Heart Infusion (BHI; Difco, Franklin Lakes, NJ, USA) culture medium for bacteria, and RPMI-1640 (Roswell Park Memorial Institute) (Angus Buffers and Biochemicals, Niagara Falls, New York, USA) for yeast. The extracts were diluted in $40 \%$ ethyl alcohol $(8 \mathrm{mg} / \mathrm{mL})$ and tested at concentrations from 15.62 to $2000 \mu \mathrm{g} / \mathrm{mL}$. A total of $100 \mu \mathrm{L}$ of standardized bacterial [ $1.0 \times 10^{6}$ colonyforming units (CFU) $/ \mathrm{mL}$ ] or fungal $\left(5.0 \times 10^{3} \mathrm{CFU} / \mathrm{mL}\right)$ inocula were added into each well.

The positive controls were $0.12 \%$ chlorhexidine (Sigma-Aldrich, St. Louis, MO, USA) and nystatin (SigmaAldrich, St. Louis, MO, USA) and the negative control was $40 \%$ ethyl alcohol. The plates were incubated at $37^{\circ} \mathrm{C}$ for 24 hours. The MIC was considered as the lowest extract concentration able to inhibit visible microbial growth, subsequently confirmed by $0.01 \%$ resazurin staining (Sigma-Aldrich, St. Louis, MO, USA).

To determine the bactericidal or fungicidal activity of the extracts, MBC/MFC tests were carried out by plating aliquots of MIC and higher concentrations onto specific culture media (BHI agar for bacteria and Sabouraud 
dextrose agar for yeast). The MBC/MFC was defined as the lowest concentration able to inhibit any microbial growth on the solid culture medium. All tests were performed in triplicate in three independent experiments.

\section{Inhibition of $C$. albicans Biofilm Adhesion}

Based on the results of MIC and MBC/MFC, tests of inhibition of biofilm adhesion were performed only with the extract of $B$. forficata against $C$. albicans. Biofilms were grown on 96-well plates (Techno Plastic Products AG, Trasadingen, Switzerland). Initially, $100 \mu \mathrm{L}$ of a microbial suspension containing $10^{5} \mathrm{CFU} / \mathrm{mL}$ cultured in RPMI1640 plus $2 \%$ sucrose was transferred to each well of the plate containing the extract at concentrations ranging between 15.62 and $2000 \mu \mathrm{g} / \mathrm{mL}$. Then the plates were incubated for 48 hours at $35^{\circ} \mathrm{C}$ with shaking $(75 \mathrm{rpm})$. Untreated biofilms were used as a negative control, and nystatin was used as positive control. The assays were performed in triplicate in three independent experiments. To quantify the adherent cells, the wells were washed with distilled water and dried at room temperature for 45 minutes. Subsequently, $200 \mu \mathrm{L}$ of $1 \%$ crystal violet aqueous solution was added. The wells were washed and destained with $200 \mu \mathrm{L}$ of $95 \%$ ethanol for 45 minutes. One hundred and fifty microliters of the destained solution was transferred to a new 96-well plate, and the amount of crystal violet was measured at $525 \mathrm{~nm}$ using a microplate reader (SpectraMax 340 Tunable Microplate Reader; Molecular Devices Inc., California, USA). The absorbance values of the experimental groups were subtracted from the values of the negative control, to assess the amount of adhered microbial cells. ${ }^{21,22}$

\section{Antiproliferative Assay}

A human keratinocyte cell line (HaCaT) and six human tumor cell lines were used: NCI-ADR/RES (ovary with phenotype resistance to multiple drugs), 786-O (kidney), NCI-H460 (lung), OVCAR-3 (ovary), HT-29 (colon), and K562 (bone marrow). All lines were cultivated in 25-mL vials with $5 \mathrm{~mL}$ of RPMI-1640 medium (Gibco-BRL, Grand Island, New York, USA), supplementing with $5 \%$ bovine fetal serum (Gibco-BRL, Grand Island, New York, USA), adding further a mixture of penicillin-streptomycin (1000 $\mathrm{U} / \mathrm{mL}: 1000 \mu \mathrm{g} / \mathrm{mL}, 1 \mathrm{~mL} / \mathrm{L} \mathrm{RPMI})$ at $37^{\circ} \mathrm{C}$ in a humidified atmosphere with $5 \% \mathrm{CO}_{2}$. The cultures were placed in 96-well plates (100 $\mu \mathrm{L} /$ well) and exposed to extracts diluted in sodium dimethyl sulfoxide at a concentration of $0.1 \mathrm{gm} / \mathrm{mL}$ (DMSO, Sigma-Aldrich, St. Louis, MO, USA) standing for 24 hours at $37^{\circ} \mathrm{C}$ in a humidified atmosphere with $5 \% \mathrm{CO}_{2}$. Before $\left(\mathrm{T}_{0}\right)$ and after the addition of the sample $\left(T_{1}\right)$, the cells were fixed with $50 \%$ trichloroacetic acid and cell proliferation was determined by spectrophotometric measurement $(540 \mathrm{~nm})$ of the protein content, using sulforhodamine B. A concentration-response curve for each cell line was determined by nonlinear regression analysis using Origin 8.0 (OriginLab Corporation) software to establish $50 \%$ growth inhibition $\left(\mathrm{GI}_{50}\right)$, which is the concentration of the hydroalcoholic plant extract required to inhibit $50 \%$ cell growth.

\section{RESULTS}

\section{MIC and MFC/MBC}

The extract of B. forficata showed strong antifungal activity against $C$. albicans, with MIC values of $15.62 \mu \mathrm{g} / \mathrm{mL}$ and MFC higher than $2000 \mu \mathrm{g} / \mathrm{mL}$, indicating a fungistatic effect. For all other strains (S. mutans, S. sanguis, and E. faecalis), the results of MIC and MBC were higher than $2000 \mu \mathrm{g} / \mathrm{mL}$. None of the strains tested were susceptible to $C$. quercifolius leaf extract at concentrations up to $2000 \mu \mathrm{g} / \mathrm{mL}$.

\section{Inhibition of $C$. albicans Biofilm Adhesion and SEM Analysis}

As seen in Graph 1, the extract of B. forficata inhibited biofilm adhesion by 33 to $45 \%$ at concentrations higher than $7.81 \mu \mathrm{g} / \mathrm{mL}$, showing a pattern very similar to that of the monodrug nystatin. Scanning electron microscopy (SEM) images revealed alterations in the morphology of $C$. albicans biofilm cells treated with the extract of $B$. forficata, with differences in structure and integrity as compared with the untreated control (Fig. 1).

\section{Antiproliferative Activity}

The extracts of B. forficata and C. quercifolius showed nonspecific cytotoxic activity against tumor cell lines. There was inhibition of tumor cell growth with mean log

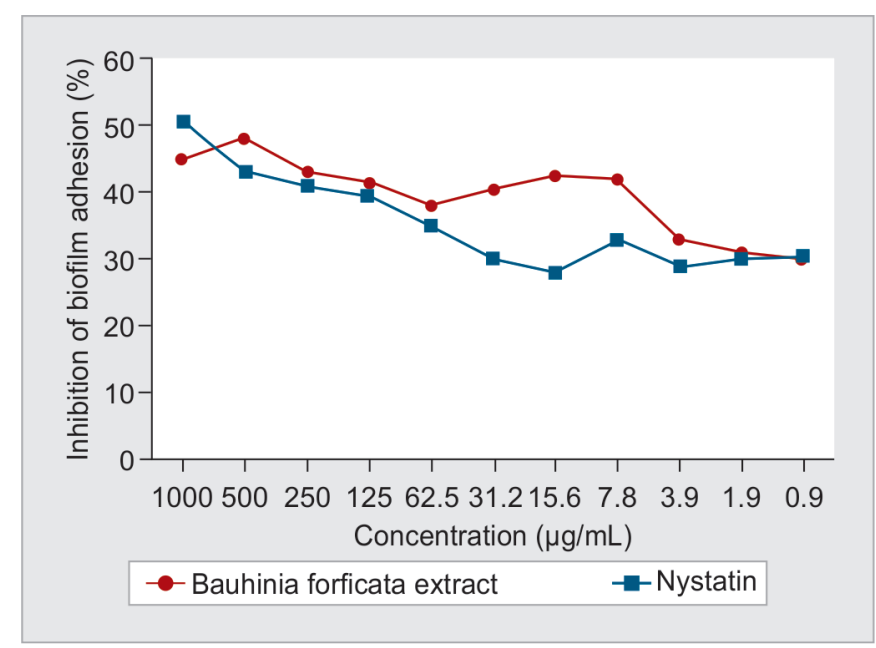

Graph 1: Inhibitory effects of different concentrations of $B$. forficata extract and nystatin (standard antifungal) on biofilm adhesion of C. albicans ATCC 18804 



Figs 1A to C: Effects on biofilm structure. Scanning electron microscopy photomicrographs $(\times 5000$ magnification $)$ of $C$. albicans ATCC 18804 biofilms treated with: (A) B. forficata Link extract - $15.62 \mu \mathrm{g} / \mathrm{mL}$; (B) nystatin $(1 \mathrm{mg} / \mathrm{mL})$; and (C) untreated control

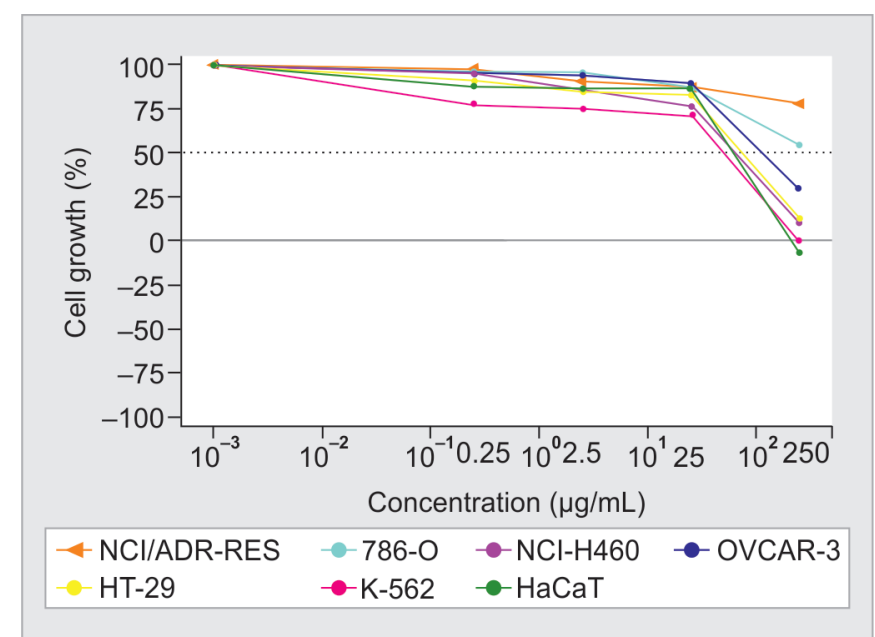

Graph 2: Distribution of cell growth inhibition values in human tumor cells treated with $B$. forficata link extract. NCI-ADR/RES (ovary with phenotype resistance to multiple drugs), 786-O (kidney), $\mathrm{NCl}-\mathrm{H} 460$ (lung), OVCAR-3 (ovary), HT-29 (colon), K562 (bone marrow), and $\mathrm{HaCaT}$ (normal keratinocyte cell line). $\mathrm{Gl}_{50}, 50 \%$ inhibition of cell growth

$\mathrm{GI}_{50}=2.01 \mu \mathrm{g} / \mathrm{mL}$ (Graph 2) for B. forficata and $2.4 \mu \mathrm{g} / \mathrm{mL}$ (Graph 3) for C. quercifolius. The results with the positive control (doxorubicin) are shown in Graph 4. For cytostatic effects, curve points are above zero, while for cytocidal effects curve points are below zero; and in the case of total inhibition of growth, $\mathrm{T}$ is equal to $\mathrm{T}_{0}$, indicating that the substance causes $100 \%$ cell inhibition (total GI).

\section{DISCUSSION}

There has been an increasing interest in bioprospecting natural products as a source of novel molecules for drug development. ${ }^{1}$ Herein, we investigated the antimicrobial and antiproliferative potential of extracts of plants commonly used in folk medicine, B. forficata and C. quercifolius.

The antimicrobial assays carried out in this study showed the strong antifungal potential of $B$. forficata extract against $C$. albicans, but not against streptococci and $E$. faecalis. These findings are in line with those of a previous bioprospection study on medicinal plants of



Graph 3: Distribution of cell growth inhibition values $\left(\mathrm{GI}_{50}\right)$ in human tumor cells treated with $C$. quercifolius extract. NCI-ADR/ RES (ovary with phenotype resistance to multiple drugs), 786-O (kidney), NCl-H460 (lung), OVCAR-3 (ovary), HT-29 (colon), K562 (bone marrow), and HaCaT (normal keratinocyte cell line)

the semiarid region of northeastern Brazil. ${ }^{23}$ It has been reported that substances showing MIC up to $500 \mu \mathrm{g} / \mathrm{mL}$ are considered strong antimicrobial agents; moderate if between 500 and $1000 \mu \mathrm{g} / \mathrm{mL}$; and weak if above 1000 $\mu \mathrm{g} / \mathrm{mL}^{24,25}$ With a MIC of $15.62 \mu \mathrm{g} / \mathrm{mL}$ against planktonic C. albicans, B. forficata extract was further selected to be tested against $C$. albicans biofilm adhesion. On the contrary, the findings of this study do not support the use of C. quercifolius as an antimicrobial agent, as its MIC was found to be $>2000 \mu \mathrm{g} / \mathrm{mL}$ against all tested strains.

It is known that the ability of a pathogenic microorganism to form biofilm is related to its adhesion potential and the expression of virulence factors. ${ }^{26}$ Microbial adhesion to an abiotic or biotic surface is a critical step for yeast surface colonization and further mature biofilm formation. Hence, inhibition of biofilm adhesion is considered an effective target for the development of antimicrobial drugs. In this study, we showed that B. forficata extract was able to disrupt biofilm adhesion 


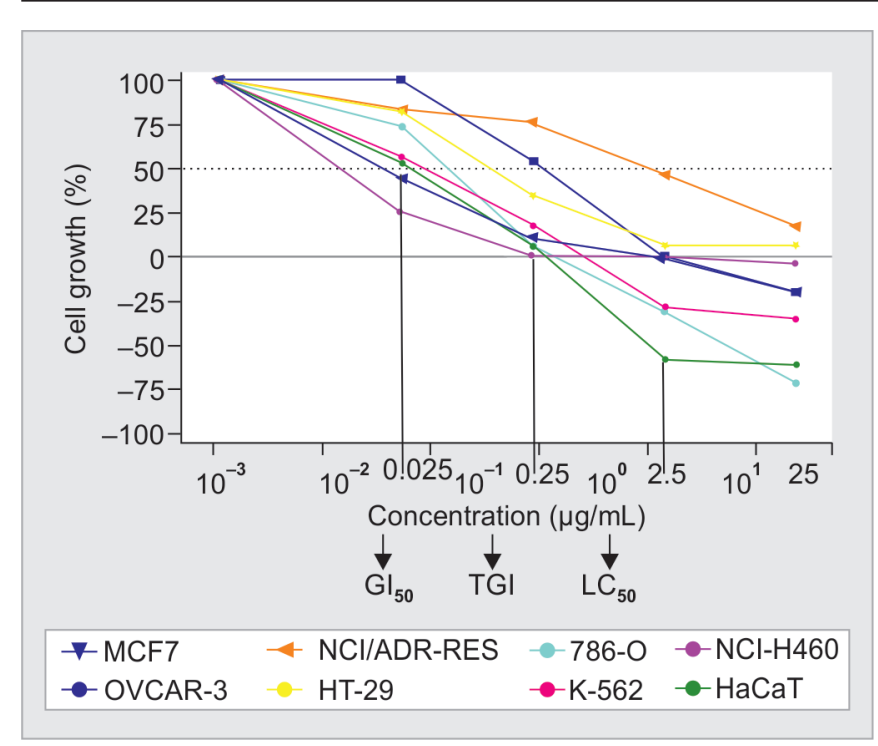

Graph 4: Distribution of cell growth inhibition values in human tumor cells treated with doxorubicin (positive control). MCF7 (breast) $\mathrm{NCl}-\mathrm{ADR} / \mathrm{RES}$ (ovary with phenotype resistance to multiple drugs), 786-O (kidney), NCl-H460 (lung), OVCAR-3 (ovary), HT-29 (colon), K562 (bone marrow), and HaCaT (normal keratinocyte cell line). $\mathrm{GI}_{50}, 50 \%$ growth inhibition; TGI, total growth inhibition; $\mathrm{LC}_{50}$, concentration required for $50 \%$ cell death

at concentrations as low as $7.8 \mu \mathrm{g} / \mathrm{mL}$ (subinhibitory concentration), which was comparable to the standard drug nystatin. Furthermore, SEM analysis revealed that this extract clearly affected biofilm structure and integrity at MIC. This may be a result of changes in the cell wall structure or altered membrane permeability in the yeast cell. Bioactive molecules present in the extract may act on the cell membrane and/or the intracellular components, with disruption of vital cellular processes, such as the synthesis of deoxyribonucleic acid, ribonucleic acid, or proteins. ${ }^{22}$ Studies of mechanism of action are now encouraged to further investigate the antifungal potential of B. forficata.

In recent years, an active search for novel antiproliferative agents has also become increasingly necessary. With this purpose, immunological and pharmacological therapies have been tested to find more effective approaches for the treatment of tumors. ${ }^{27}$ Therefore, the extracts of B. forficata and C. quercifolius were also tested for their antiproliferative potential against six tumor cell lines and one normal cell line of keratinocytes. The concentration-response curve is one of the best ways to visualize the antiproliferative activity of a given sample. Agents are considered active if $\mathrm{GI}_{50} \leq 30 \mathrm{\mu g} / \mathrm{mL}^{28}$ The US National Cancer Institute in the anticancer drug screening program considers $\mathrm{GI}_{50}$ values $\leq 4.0 \mathrm{\mu g} / \mathrm{mL}$ as having strong antineoplastic activity. ${ }^{29}$ The extracts of $B$. forficat $a$ and C. quercifolius inhibited the growth of tumor cells nonspecifically and were characterized as cytostatic and not as cytocidal agents. ${ }^{30}$ Notably, B. forficata extract did not affect normal cells (HaCat) even at concentrations higher than its MIC, which indicates a low cytotoxic profile.

It is worth noting that among the various methods described for obtaining extracts, we selected the hydroalcoholic extraction - analogous to the tinctures made in folk medicine - in which the active parts of the plants are mixed with alcoholic beverages. ${ }^{31}$ The findings reported herein contribute to the scientific literature on the study of these species and aggregate scientific value to their use in folk medicine, particularly B. forficata extract.

\section{CONCLUSION}

In summary, the extract of $B$. forficata showed strong antimicrobial activity against $C$. albicans and was able to disrupt biofilm adhesion at low concentrations. Further research is suggested to assess the antifungal mechanism of action by which B. forficata extract affects yeast cells. The antiproliferative assays indicated that the extracts of B. forficata and C. quercifolius have cytostatic potential against tumor cells and should be further investigated for their antitumor activity.

\section{CLINICAL SIGNIFICANCE}

The study of medicinal plants as a source of new types of drugs has grown in recent years due to the search for new drugs with greater therapeutic activity, lower toxicity, better biocompatibility, and more accessibility to the population, which, due to cultural aspects, has a good acceptance, reflecting good prospects in the market of therapeutic products made from active natural ingredients. Therefore, studies are needed for the discovery of safe, stable drugs from sources found in nature that are effective against resistant fungi.

\section{ACKNOWLEDGMENT}

Authors would like to thank the State University of Paraíba, Coordination for the Improvement of Higher Education Personnel, and the National Council for Scientific and Technological Development, Brazil for supporting this study.

\section{REFERENCES}

1. Newman DJ, Cragg GM. Natural products as sources of new drugs over the 30 years from 1981 to 2010. J Nat Prod 2012 Feb;75(3):311-335.

2. da Cunha AM, Menon S, Menon R, Couto AG, Bürger C, Biavatti MW. Hypoglycemic activity of dried extracts of Bauhinia forficata Link. Phytomedicine 2010 Jan;17(1):37-41.

3. Ferreres F, Gil-Izquierdo A, Vinholes J, Silva ST, Valentão P, Andrade PB. Bauhinia forficata Link authenticity using flavonoids profile: relation with their biological properties. Food Chem 2012 Sep;134(2):894-904.

4. Pinheiro TS, Johansson LA, Pizzolatti MG, Biavatti MW. Comparative assessment of kaempferitrin from medicinal 
extracts of Bauhinia forficata link. J Pharm Biomed Anal 2006 May;41(2):431-436.

5. Silva FR, Szpoganicz B, Pizzolatti MG, Willrich MA, de Sousa E. Acute effect of Bauhinia forficata on serum glucose levels in normal and alloxan-induced diabetic rats. J Ethnopharmacol 2002 Nov;83(1-2):33-37.

6. Agra MF, Freitas PF, Barbosa-Filho JM. Synopsis of the plants known as medicinal and poisonous in Northeast of Brazil. Braz J Pharmacogn 2007Jan/Mar;17(1):114-140.

7. Sobrinho TJSP, Castro VTNA, Saraiva AM, Almeida DM, Tavares EA, Pisciottano MNC, de Amorim ELC. Phytochemical screening and antibacterial activity of four Cnidoscolus species (Euphorbiaceae) against standard strains and clinical isolates. J Med Plants Res 2012 Jun;6(21):3742-3748.

8. Filho NMR, da Silva Caldeira VP, Florêncio IM, Azevedo DO, Dantas JP. Avaliação comparada dos índices químicos nitrogênio e fósforo nas porções morfológicas das espécimes de faveleira com espinhos e sem espinhos. Rev Bras Prod Agroind 2007;9(2):149-160.

9. Roque AA, Rocha RM, Loiola MIB. Uso e diversidade de plantas medicinais da caatinga na comunidade rural de Laginhas, município de Caicó, Rio Grande do Norte (nordeste do Brasil). Rev Bras Plantas Med 2010 Jan/Mar;12(1):31-42.

10. Maciel MAM, Pinto AC, Veiga VF Jr. Plantas medicinais: a necessidade de estudos multidisciplinares. Quim Nova 2002;25(3):419-438.

11. Pinto PM, Weikert-Oliveira RC, Lyon JP, Cury VF, Arantes RR, Koga-Ito CY, Resende MA. In vitro antifungal susceptibility of clinical isolates of Candida spp. Obtained from patients with different predisposing factors to Candidosis. Microbiol Res 2008 Sep;163(5):579-585.

12. Gehrke IT, Neto AT, Pedroso M, Mostardeiro CP, da Cruz IB, Silva UF, Iiha V, Dalcol II, Morel AF. Antimicrobial activity of Schinus lentiscifolius (Anacardiaceae). J Ethnopharmacol 2013 Jul;148(2):486-491

13. Nirmala MJ, Mukherjee A, Chandrasekaran N. Improved efficacy of fluconazole against candidiasis using bio-based microemulsion technique. Biotechnol Appl Biochem 2013 Jul-Aug;60(4):417-429.

14. Singh D, Kumar TR, Gupt VK, Chaturvedi P. Antimicrobial activity of some promising plant oils, molecules and formulations. Indian J Exp Biol 2012 Oct;50(10):714-717.

15. Alves PM, Queiroz LM, Pereira JV, Pereira Mdo S. In vitro antimicrobial, antiadherent and antifungal activity of Brazilian medicinal plants on oral biofilm microorganisms and strains of the genus Candida. Rev Soc Bras Med Trop 2009 Mar-Apr;42(2):222-224.

16. Ncube B, Finnie JF, Van Staden J. In vitro antimicrobial synergism within plant extract combinations from three South African medicinal bulbs. J Ethnopharmacol 2012 Jan;139(1):81-89.

17. Palombo EA. Traditional medicinal plant extracts and natural products with activity against oral bacteria: potential application in the prevention and treatment of oral diseases. Evid Based Complement Alternat Med 2011;2011:680354.
18. Pereira EM, Gomes RT, Freire NR, Aguiar EG, Brandão Md, Santos VR. In vitro antimicrobial activity of Brazilian medicinal plant extracts against pathogenic microorganisms of interest to dentistry. Planta Med 2011 Mar;77(4):401-404.

19. Clinical and Laboratory Standards Institute. Methods for dilution antimicrobial susceptibility tests for bacteria that grow aerobically; approved standard. 8th ed. Vol. 29. Wayne (PA): Clinical and Laboratory Standards Institute; 2009.

20. Clinical and Laboratory Standards Institute. Reference method for broth dilution antifungal susceptibility testing of yeasts; approved standard. 3rd ed. Vol. 28. Wayne (PA): Clinical and Laboratory Standards Institute; 2008.

21. Freires IA, Murata RM, Furletti VF, Sartoratto A, Alencar SM, Figueira GM, Rodrigues JAO, Durate MCT, Rosalen Pl. Coriandrum sativum L. (coriander) essential oil: antifungal activity and mode of action on Candida Spp., and molecular targets affected in human whole-genome expression. PLoS One 2014 Jun;9(6):e99086.

22. Li X, Yan Z, Xu J. Quantitative variation of biofilms among strains in natural populations of Candida albicans. Microbiology 2003 Feb;149(Pt 2):353-362.

23. Silva MSP, Brandão DO, Chaves TP, Formiga Filho ALN, Costa EMMB, Santos VL, Medeiros ACD. Study bioprospecting of medicinal plant extracts of the semiarid northeast: contribution to the control of oral microorganisms. Evid Based Complement Alternat Med 2012 Apr;2012:681207.

24. Aligiannis N, Kalpoutzakis E, Mitaku S, Chinou IB. Composition and antimicrobial activity of the essential oils of two Origanum species. J Agric Food Chem 2001 Sep;49(9): 4168-4170.

25. Freires IA, Denny C, Benso B, de Alencar SM, Rosalen PL. Antibacterial activity of essential oils and their isolated constituents against cariogenic bacteria: a systematic review. Molecules 2015 Apr;20(4):7329-7358.

26. Khan MS, Ahmad I, Cameotra SS, Botha F. Sub-MICs of Carum copticum and Thymus vulgaris influence virulence factors and biofilm formation in Candida Spp. BMC Complement Altern Med 2014 Sep;14:337.

27. Chabner BA, Roberts TG Jr. Timeline: chemotherapy and the war on cancer. Nat Rev Cancer 2005 Jan;5(1):65-72.

28. Itharat A, Houghton PJ, Eno-Amooquaye E, Burke PJ, Sampson JH, Raman A. In vitro cytotoxic activity of Thai medicinal plants used traditionally to treat cancer. J Ethnopharmacol 2004 Jan;90(1):33-38.

29. Suffness, SM.; Pezzuto, JM. Assays for cytotoxicity and antitumor activity. In: Hostettmann K, editor. Methods in plant biochemistry. Vol. 6. London: Academic press; 1991. p. 71-133.

30. Atjanasuppat K, Wongkham W, Meepowpan P, Kittakoop P, Sobhon P, Bartlett A, Whitfield PJ. In vitro screening for anthelmintic and antitumour activity of ethnomedicinal plants from Thailand. J Ethnopharmacol 2009 Jun;123(3):475-482.

31. Cechinel-Filho V, Yunes RA. Estratégias para a obtenção de compostos farmacologicamente ativos a partir de plantas medicinais. Conceitos sobre modificação estrutural para otimização da atividade. Quím Nova 1998;21(1):99-105. 